\title{
Sustainable use and incentive-driven conservation: realigning human and conservation interests
}

\author{
Jon M. Hutton and Nigel Leader-Williams
}

\begin{abstract}
Discussions of sustainable use have become polarized. Welfarists oppose all use that involves killing animals. Among conservationists polarization arises in part from failure to distinguish between different ideas nestled under the umbrella term of 'sustainable use'. These include direct use as an imperative or choice, the ideal of keeping any use within biologically sustainable limits, and use as a possible conservation strategy that can create positive incentives, which are key where land could otherwise be converted to biodiversity-unfriendly practices. People will continue to use wild living resources, which increasing human populations could further deplete. In response the conservation community can follow one of two approaches. On the one hand, it can try to stop use through the establishment of strictly protected areas and by enforcing legislation, although many would question the ethical position of imposing such an approach. On the other hand, it can work to intro-
\end{abstract}

duce the wider management systems needed to deliver sustainable use and, if possible, incentive-driven conservation. Because most rural populations will continue using wild living resources in human-dominated landscapes, sustainable use and incentive-driven conservation should both be at the centre of the conservation agenda this century. Both species- and ecosystem-based management are likely to have a role in sustainable use. However, current enthusiasm for the ecosystem approach may throw up unexpected consequences, making the search for sustainability even more polarized. Nevertheless, direct use of species cannot provide sufficient incentives to ensure the continued delivery of ecosystem services, which need to be fully incorporated in the global accounting system.

Keywords Adaptive management, ecosystem services, incentive-driven conservation, incentives, sustainable use.

\section{Introduction}

The direct use of wild living resources still remains an imperative or choice for many people, while all of humanity depends on the indirect use of ecosystem services. However, the direct extractive use of wild living resources is opposed by those who object to the killing and collecting of certain groups of species on ethical and moral grounds. Furthermore, many are concerned that extractive use of many wild living resources has been, and continues to be, biologically unsustainable. Markets and commerce have often featured in the overuse of animals and plants that have relatively slow rates of reproduction (Clark, 1973). As a result, many promote apparently benign nature-based tourism over

Jon Hutton (Corresponding author) Fauna \& Flora International, Great Eastern House, Tenison Road, Cambridge, CB1 2TT, UK. E-mail: jon.hutton@fauna-flora.org

Nigel Leader-Williams Durrell Institute of Conservation and Ecology, Department of Anthropology, University of Kent, Canterbury, CT2 7NS, UK.

Received 10 March 2003. Revision requested 21 March 2003. Accepted 4 April 2003. extractive uses. Equally, it is often considered that biological sustainability is not alone a sufficient condition for use, which should provide economic or social incentives that serve as a tool for conservation. Confusion and conflict arise, in part at least, because of the different ideas of use, sustainability and incentive presently gathered under the umbrella of 'sustainable use', and from our failure to derive adequate terminology to distinguish between these ideas. More importantly, the promotion of sustainable use as a conservation tool has been insufficiently monitored, and there are few cases where extractive use has been shown to have unequivocally enhanced conservation efforts (Rasker \& Freese, 1995). Firstly, therefore, we seek to tease out some of the different ideas that currently nestle under the umbrella term of sustainable use, what it is and what it is not, and to introduce the term 'incentivedriven conservation'. Secondly, we reflect on the search for management systems that will ensure use of wild living resources remains within sustainable limits.

This is no small challenge, and mirrors the controversy that IUCN faced over two decades in developing its Policy Statement on Sustainable Use of Wild Living Resources (IUCN, 2000). Although this policy was 
eventually adopted by acclaim and with little discussion, the assumption that everyone in the wider conservation community understands and supports sustainable use does not hold (e.g. Lavigne et al., 1996). It is understandable that extractive use of wild species makes many conservationists very nervous (Caughley \& Gunn, 1996; Milner-Gulland \& Mace, 1998), given that overuse remains a key factor that threatens species (HiltonTaylor, 2000) and that it was a key factor responsible for documented extinctions (Diamond, 1989). Nevertheless, the Convention on Biological Diversity (CBD) has achieved broad, although often somewhat superficial, international consensus through its ratification by nearly 190 countries, and makes sustainable use one of its three central pillars that link people and the natural world. Because the use of wild living resources remains an essential livelihood strategy for many, use that is biologically sustainable, with the potential to provide incentives for conservation, seems a clear goal for which to strive. Equally, humanity faces considerable challenges over the coming decades to achieve this goal. Anyone with an interest in resource conservation, whether their focus is human welfare or biodiversity conservation, should be concerned with addressing this challenge rather than dismissing it as impossible to achieve.

\section{What sustainable use is and what it is not}

Several ideas currently nestle under the umbrella term of 'sustainable use'. These include use as an imperative or choice in the pursuit of livelihood strategies, the need to manage use to achieve biological sustainability, and the possibility that use can provide incentives to conserve biodiversity. The links between these ideas have been articulated on several occasions (e.g. Robinson, 1993, 1998, 2001; Freese, 1997). Because much confusion arises in debates over sustainable use because of inadequate and misunderstood terminology, we seek to explore what sustainable use is and what it is not.

Article 2 of the CBD defines sustainable use as "the use of components of biological diversity in a way and at a rate that does not lead to the long-term decline of biological diversity, thereby maintaining its potential to meet the needs and aspirations of present and future generations". This definition is noteworthy for two reasons. Firstly, the italicized words mainly encompass the search for biological sustainability in order that species and ecosystems are available for use over the long-term. Secondly, the definition embraces all forms of use and does not focus solely on particular forms of use. The CBD, therefore, considers that sustainable use is about managing any use of wild species and ecosystems so that it falls within biologically sustainable limits. The
CBD definition neutralizes three common confusions about sustainable use (Robinson, 1998), namely that is only about consumptive use, that it necessarily involves local communities, and that it is necessarily about creating incentives and turning use into a conservation tool. The use of biodiversity can, and often does, involve commercial and extractive use, may be undertaken by many local communities, and can create incentives for sustainable use. Nevertheless, it does not have to, because biological sustainability may be better enhanced by other mechanisms under certain circumstances (Robinson, 1998).

\section{Use of wild living resources as an imperative or choice}

Human societies have depended on the extractive use of wild living resources for most of their existences (Leakey, 1981). However, as certain species were domesticated, as land became steadily converted for either agricultural, industrial or urban use, and as synthetic substitutes were developed, many modern human societies have come to depend less on the extractive use of wild species. Nevertheless, use of wild species still remains the foundation for human survival in much of the developing world (Eltringham, 1984; Prescott-Allen \& Prescott-Allen, 1982; Redford \& Robinson, 1991; Scoones et al., 1992; Cunningham, 2001), where some 300 million people in traditionally organized societies occupy nearly one-fifth of the earth's surface. Thus, nearly $40 \%$ of a sample of non-agricultural and non-industrialized societies heavily depend on fishing, c. $33 \%$ depend on gathering, and $28 \%$ depend on hunting of terrestrial resources (Ingold et al., 1988). Rural villages in agriculturally marginal areas of Tanzania still derive c. $60 \%$ of household income from the harvesting and sale of wild honey, wild fruits, charcoal and fuel wood (Monela et al., 1999). Equally, the world's more industrialized and agriculturally dependent economies still consume many products from wild-taken species, heavily harvest fish and forestry resources, and exploit many wild species in their rural areas. Even though little use may be expected of wild living resources in a heavily populated and industrialized country such as Britain, the use of wild species remains an important need and choice for many rural livelihoods (Sanderson \& Prendergast, 2002). Urban wealth may also drive extensive use of many wild species, for example in some parts of Asia (TRAFFIC, 2003).

Where the extractive use of wild species and ecosystems is an imperative, rates of use from those remaining fragments of wild species and natural ecosystems will probably continue to rise (Robinson, 2001) 
as human populations increase further and people seek to meet their needs from 'free' wild resources under a range of adverse economic and environmental conditions (Hutton \& Dickson, 2001). Furthermore, as human populations increase globally they will seek to appropriate more than the current $40 \%$ of net primary production they currently use or divert (Vitousek et al., 1986), encroach further into the territories of wild species, and exacerbate conflict with the remaining fragments of wildlife (Knight, 2000). Therefore, under current projections, more wild species will be replaced by cultivated or domesticated species, and more natural ecosystems will be replaced by agricultural land. In western industrialized agricultural countries, this conversion is forced further by enormous perverse subsidies that promote use of herbicides, pesticides and nitrogenous fertilisers (Myers \& Kent, 2001). The combination of direct use and habitat loss results in unsustainable offtake of many, if not most, wild living resources. Therefore, the prognosis is unhappy for the species threatened by overuse (Hilton-Taylor, 2000), for the people whose livelihoods depend directly or indirectly on the use of these resources (Roe et al., 2002), and for those ultimately affected by the loss of environmental services as ecosystems lose their functions (Daily, 1997). Nevertheless, where human well-being is markedly dependent on particular wild living resources, the extractive use of wild species and natural ecosystems will inevitably continue.

Not all species or ecosystems, however, may be directly subjected to extractive use. Most human cultures have religious beliefs about, and ritual uses of, plants and animals that ensure indigenous commitment to the conservation of these species and habitats (Orlove \& Brush, 1996). Taboos represent unwritten social rules that regulate human behaviour, and may play an important local role in conserving wild living resources (Colding \& Folke, 1997). In many traditional societies, taboos may be associated with particular habitat patches set aside for religious purposes (Gadgil \& Vartak, 1974), and may be the only pristine habitat remaining locally. Under current rates of habitat and species loss, culturally defined taboos may play an increasingly important role in conserving biodiversity (Colding \& Folke, 1997). Taboos may also be associated with the use of particular species, for reasons not necessarily associated with their conservation. In some places, for example, species are believed to be toxic or play a key role in creation myths.

Many western industrialized societies also elevate charismatic species to 'totemic' status, and oppose their use, even when this is practised by others, often on other continents. The key concern in such cases is the welfare of the individuals targeted for use, rather than the conservation of viable populations of the species and their associated habitats. When this moral position is argued out under the rubric of sustainable use, it often masks the real position that any form of extractive use of individuals of those species is unacceptable (e.g. Hoyt, 1994). Such arguments also give rise to another myth (Robinson, 1998), that sustainable use is mainly about harvesting charismatic megafauna. A moral 'anti-use' position may also coincide with some conservationists' concerns that levels of extractive use of particular species are biologically unsustainable. This adds to the tensions that arise within arenas such as the Convention on International Trade in Endangered Species of Wild Fauna and Flora (CITES) with regard to the use of charismatic species such as whales, turtles, elephants and rhinoceroses (Hutton \& Dickson, 2000).

When positions are taken against the consumptive use of charismatic species, wildlife viewing and similar types of nature-based tourism are often promoted as the option of choice for the direct use of wild living resources (Honey, 1999). Tourism is now one of the world's largest and fastest growing industries, and nature-based tourism, which encompasses all forms and scales of tourism that result from the enjoyment of natural areas and wildlife, is the largest growing sector of that industry (Roe et al., 1997; Leader-Williams, 2002a). However, some natural areas are generally better suited to attracting tourists than others, usually because of the combination of good visibility and presence of charismatic species (Goodwin \& Leader-Williams, 2000). Where this is the case, such tourism promotes the direct use of species and ecosystems without the need for intentional killing or extractive use. In turn, there is an implicit assumption that this form of use will be biologically sustainable. However, large and increasing numbers of tourists often have impacts, both direct and indirect, on natural ecosystems (Roe et al., 1997), as well as on the culture of local people, so neither biological nor social sustainability can be presumed.

\section{The search for biological sustainability}

Extractive use of species occurs on the one hand where the individuals from which parts are removed remain alive in the wild population and, on the other hand, where individuals are removed entirely from the wild population. This distinction is important because each approach is underlain by different theoretical and practical implications (Caughley \& Gunn, 1996; Leader-Williams, 2002b).

When products such as down from eider duck nests, nests from swiftlets, sheared wool from vicuña, venom from snakes, nuts from trees or wood from coppiced trees are collected, the individuals may remain 
alive in the population. The population may be affected, for example through disturbance to remaining wild individuals, but generally, the highest sustainable productivity comes when populations are at their largest size or maximum carrying capacity. Little theory is involved, except with regard to determining optimum rotation times between harvests (Milner-Gulland et al., 1992; Lim \& Cranbrook, 2002). The decision on whether to harvest or not to harvest, and at what levels, is largely based on the likely success of measures to prevent illegal or unregulated offtake and/or the effects of allowing a legal trade upon other related species and populations.

Where individuals are removed entirely from the wild population this may involve lethal extraction through logging, hunting or fishing, for example, or non-lethal extraction through collection or live capture. Some think of the removal of live animals or plants as 'nonconsumptive' use. However, in biological terms this is a nonsense as the effect is still to remove an individual from the population. For this reason, we have adhered to the generic term 'extractive use', rather than become muddled in the complications of 'consumptive' and 'non-consumptive' use. Where individuals are removed from wild populations, the highest sustainable productivity generally comes when populations are below their largest size or maximum carrying capacity. The biologically optimal harvesting strategy lowers population density and then extracts at the speed with which the population rebounds. Hence, such harvesting always reduces population density during the first few years of operation, but this initial decline does not necessarily indicate over-utilization (Caughley \& Gunn, 1996). Nevertheless, many harvesting operations have used species in ways and at rates that have proved biologically unsustainable, leading directly to stock collapse. Particularly susceptible are those long-lived species with low intrinsic rates of increase and low adult mortality, those that provide food or marketable commodities, and those for which the economics of exploitation favour the immediate 'mining' of wild populations rather than their long-term sustainable use (Clark, 1973, 1990; Diamond, 1989). Resource uses that have been dramatically unsustainable at one time or another include the North America seal, sea lion and fur seal trades, the Southern Ocean whaling industry, the bluefin tuna fishing industry, the logging of mahogany, and the hunting of many larger bodied animals for food (or bushmeat) in tropical forests (e.g. Robinson \& Bennett, 2000; Ludwig, 2001). Such examples have been used to develop the theory and models that underpin our now considerable knowledge of biological limits to the sustainability of harvesting (Clark, 1990; Robinson \& Redford, 1991; Caughley \& Gunn, 1996; Robinson \& Bennett, 2000; Reynolds et al., 2001).
In some instances biological knowledge can inform how to move the ways and rates at which systems are used towards greater sustainability. Determining optimum rotation times is important in situations where parts are harvested from individuals that remain in the wild population. Equally, biological knowledge can also improve situations where individuals are removed from the wild population. For example, a switch was made in the 1980s from over-harvesting adult crocodilians, which are characterized by their longevity and low rates of mortality, to 'ranching' based on the collections of eggs and juveniles, which naturally suffer high mortality and would be lost to the wild population anyway (Hutton \& Games, 1992). Other switches to more sustainable parts of the life cycle include age- and sex-structured harvesting, whereby the system seeks to move from indiscriminate harvesting of large numbers of specimens, including productive and low mortality segments of the population, to more selective harvests based on higher mortality segments, such as juveniles, and less productive segments, such as adult males (Caughley, 1977). The latter case, for example, comprises the focus of many well-managed trophy hunting operations, which are commonly characterized by their sustainability (Caughley \& Gunn, 1996).

The numerous examples of over-harvest and collapsed stocks cause many to express concerns that "the concept of sustainable use will give a green light to exploitative use" (Robinson, 1993). One response to this scenario argues for a two-pronged strategy to conserve wild species and natural ecosystems. The first is to preserve as much biodiversity as possible within strictly protected areas (e.g. Noss, 1991; Oates, 1995; Terborgh, 1999) and the second is to outlaw extractive use outside these sanctuaries. Hence, many conservationists adopt the stance that ending the extractive use of natural resources is not only an option, but the preferred option. However, this ignores the reality that the human costs of conservation can be high locally. Even if it was morally acceptable (Ostrom et al., 1999), strict protection and regulation are often not effective options (Oldfield, 2003). Furthermore, if the products taken from the wild are to be replaced with domesticated substitutes, this will almost inevitably require an expansion or intensification of agriculture, with all the resultant negative impacts on wild biodiversity. Therefore, the key challenge in a world where use of wild species is inevitable is to introduce the management systems necessary to increase the likelihood that use will be biologically sustainable. In other words "the question is not whether to use wild species, but rather how to move from a system of use that is clearly not sustainable toward one that is better" (Freese, 1997). 
In contrast to the situation for extractive use, the sustainability of non-extractive tourism is rarely questioned. Tourism has resulted directly in the conservation of many world class attractions (Honey, 1999), and many conservationists make the assumption that, because the extractive use of species is not involved, such forms of tourism are sustainable. However, some conservationists remain concerned that tourism is often promoted without due consideration of longterm conservation objectives for the species and their habitats. The sustainability of nature-based tourism is a difficult topic to research (Roe et al., 1997). Nevertheless, some species and ecosystems are known to be affected by large numbers of tourists, while the wider environmental impacts of tourism and its associated infrastructure are not usually included in the balance sheets when assessing the impact of such uses on natural ecosystems.

Notwithstanding the important contribution that biological science has made, and can make, to our understanding of sustainability, moves to systems of greater sustainability most often hinge on socio-economic issues such as changes in incentive structures and management systems. This has been recognized by earlier authors describing the social and economic linkages nestled under the umbrella term of sustainable use (Robinson, 1993, 1998, 2001; Freese, 1997).

\section{Incentive-driven conservation}

Having explored what sustainable use is and what it is not, we now propose alternative terminology that will, we hope, contribute to a clearer understanding of some issues in discussions of sustainable use. In doing so, we explicitly follow Article 11 of the CBD, which states that "Each contracting party shall as far as possible and as appropriate, adopt economically and socially sound measures that act as incentives for the conservation and sustainable use of components of biodiversity".

The antipathy that sustainable use meets in some sections of the conservation community probably arises, at least in part, because the language of sustainable use has often been adopted by those who seem to be more interested in extractive overuse than in sustainability (Robinson, 1998). At the same time some conservationists are reluctant to admit that any extractive use of wild living resources could be biologically sustainable. Paradoxically, the result is the same. The idea of sustainable use is viewed as an unwelcome challenge, to be avoided by establishing more exclusive protected areas (Soulé \& Sanjayan, 1998) and by promoting non-extractive tourism (Honey, 1999). However, conservationists of an alternative persuasion recognize that such approaches are of little direct value to all but a privileged few, and particularly unjust for the rural poor in many parts of the developing world (Berkes \& Folke, 1998; Ostrom et al., 1999; O'Riordan \& StollKleeman, 2002). Only a small portion of the earth and its resources can be locked up in strictly protected areas. Even where natural areas have not yet been converted to agriculture, the amount of land that can easily be added to that already strictly protected is extremely limited, particularly in tropical areas (Janzen, 1994). In any case, many areas considered to be high priority biodiversity hotspots are also densely populated social and political 'hotbeds' (Balmford et al., 2001).

Current targets to include $10 \%$ of the earth's surface within protected areas are largely political, whereas species-area curves suggest that a $50 \%$ coverage is needed to conserve most global biodiversity (Soulé \& Sanjayan, 1998). However, at the last global count and after over a century of hard work, there were some 12,750 protected areas over 1,000 ha in size that covered $8.8 \%$ of the earth's surface (IUCN, 1998). Furthermore, as human populations have increased, the rate of protected area establishment has slowed, and it has proved increasingly difficult to establish both large protected areas and protected areas in the so-called 'strict' categories of protection (Leader-Williams et al., 1990; IUCN, 1998); i.e. areas that seek to exclude extractive activity and most human habitation (IUCN categories I-III). In direct contrast, IUCN categories IV-VI include human habitation and activity, and extractive resource use is either a secondary (IV, V) or primary (VI) objective. Approximately half of the total protected areas are in categories I-III and the rest in categories IV-VI (Pretty 2002). Furthermore, the total numbers and coverage of the two largest categories, II, the National Parks and VI, the Managed Resource Protected Areas are similar (IUCN, 1998). Therefore, it appears even less feasible to achieve 50\% coverage of exclusive protected areas, at least not without imposing considerable state-led coercion, and disenfranchising rural people from traditional practices and losing their co-operation, as so often happens when such areas are established (Ghimire \& Pimbert, 1997). Given these circumstances, it seems futile to perpetuate arguments for the separation of humans and nature (see Adams \& McShane, 1992), or arguments about the relative effectiveness of protected areas as opposed to peoplecentred approaches (Barrett \& Arcese, 1995; Bruner et al., 2001) when in many instances both approaches are operating sub-optimally.

It appears more pragmatic to recognize that most conservation will have to be achieved through cooperation in human social space (Ghimire \& Pimbert, 1997). The extractive use of living wild resources should 
continue both inside those protected areas established to allow and support use, as well as in unprotected areas (Getz et al., 1999; O'Riordan \& Stoll-Kleeman, 2002). The clear objective is a much more biodiversityfriendly mosaic of land uses driven by the livelihoods that are derived from the sustainable use of wild living resources, instead of landscapes with small islands of biodiversity in a sea of agriculture. Furthermore, such an approach would actually benefit from core areas that more strictly protect biodiversity, as confirmed recently in the marine realm where harvest yields were shown to improve around well protected core areas (Roberts et al., 2002).

Can a duel strategy of protection and of use provide additional conservation gains (Inamdar et al., 1999)? In the tropics, for example, could $80-90 \%$ of tropical terrestrial biodiversity be conserved on $5-15 \%$ of the land, compared with $10-30 \%$ on $1-2 \%$ as at present? The realization of such a vision will require partnerships that promote conservation as a competitive form of land use (McNeely, 1995). These will, of necessity, have to be driven by incentives that motivate people to conserve wild living resources, for which we now introduce the term 'incentive-driven conservation'.

Incentives can take many forms. They may apply across all forms of land ownership, whether state, communal or private. They may be social or financial, where significant empowerment and livelihood benefits accrue to the rural poor who live side-by-side with the exploited species and on whom these species ultimately depend for their continued survival (Western \& Wright, 1994; Hulme \& Murphree, 1999). They may be positive or negative, where benefits or penalties, respectively, result from particular actions. In addition, their cost can vary enormously. In the industrialized world, negative incentives based on regulation and enforcement are common (Oldfield, 2003), as are positive (and often perverse) incentives based on financial inducements in the form of subsidies or tax breaks (Myers \& Kent, 2001). Both are extremely expensive, and the cost of regulation tends to fall most heavily on the landholder, while the state tends to bear the cost of subsidies (Moyle, 2003). Incentives can flow from both extractive and nonextractive uses. In the developed world, the benefits flowing from non-extractive uses, notably tourism and wildlife viewing, are often as significant as those from extractive uses, if not more so. However, the situation is often different in the developing world: negative incentives are not uncommon but their successful implementation is more elusive (e.g. Misra, 2003) and the state is rarely in a position to provide significant financial inducements for conservation. As a result, successful conservation is forced to rely heavily on the incentives generated by use and, for a whole raft of reasons often including a lack of accessibility, infrastructure and charismatic species, by extractive use in particular (Leader-Williams, 2000).

Regulation and control are a necessary, though not sufficient, condition for sustainable use. However, any regulatory system that relies primarily on negative incentives is inherently unstable, while positive incentives are more powerful and cost effective (Murphree, 2003). Thus, some forms of extractive use, if well managed, properly monitored and based on an understanding of biological limits to use, generate significant funds and provide positive incentives to drive habitat and species conservation (Child, 1995). For example, the economic contribution from trophy hunting can be important. In Zimbabwe's well-known CAMPFIRE programme the economic engine has been sport hunting, which has contributed $90 \%$ of CAMPFIRE's revenue, with hunting of elephants having contributed $>60 \%$ of those revenues (Bond, 1994). Such cases of incentive-driven conservation should be nurtured and encouraged. The alternative is unsustainable use and ecological degradation of natural habitats that is all too often associated with deteriorating livelihoods and human welfare.

Much has been written about a basic dichotomy between extractive use that is primarily for subsistence and that which is primarily for commercial purposes. Good examples are provided by the use of wildlife in Latin America (Redford \& Robinson, 1991) and wild plants in Africa (Cunningham, 2001). A review of commercial extractive use world-wide concluded that it represents the proverbial double-edged sword (Freese, 1997). Managed well, it can be a tool for conservation, but managed badly it can lead to overexploitation and resource depletion. For conservation biology the distinction between subsistence and commercial use is irrelevant and, for management, it is severely blurred. Thus subsistence and trade are inseparable in the local use of bushmeat, and it is unhelpful to devise management interventions that focus exclusively on one or the other (Bowen-Jones, 2003).

Unfortunately, well recorded and carefully analysed examples of incentive-driven conservation are few. As a result, it remains an important challenge to elaborate the conditions under which incentives are sufficient to promote sustainable over unsustainable use. There is a direct link between the resource and those benefiting economically (McNeely, 1998), while successful conservation depends on a number of interacting factors including the size of the benefit and the way it is distributed (IUCN, 2000). In many cases, where local communities have been involved, and co-management arrangements have been implemented and proved 
successful, a common set of pre-conditions seems to have applied (Pinkerton, 1989). The key one, which provides the encouragement to take on the challenge of making use sustainable in situations where wild species have significant value to humankind, is a real or imagined crisis in stock depletion. This is such a common situation that it can be considered fundamental in the establishment of modern sustainable use regimes.

Sadly, notwithstanding the potential financial benefits that often flow from the use of living wild resources, such use has not often realized its full potential as an incentive to support habitat and species conservation objectives, or to benefit the rural poor. This is for two main reasons. Firstly, host countries do not receive the full benefit of the revenues generated by direct use. Heavily globalized and commercialized industries such as tourism and wildlife trade result in an extensive leakage of foreign exchange from biodiversity-rich countries (e.g. Lundberg et al., 1995). Secondly, relatively little of the revenue generated accrues, directly or indirectly, either to protected area managers or to local communities. The fees and charges that accompany use fail to capture both the full willingness of consumers to pay and the real value of wild living resources and protected areas, and so national and local economies do not realize the full economic potential of the resource. For example, an analysis of the flow of money spent on a package tour to a natural area in a developing country shows that only c. $0.1-1 \%$ of total tourism expenditure is captured by the resource-rich area in entrance fees and charges, less than $10 \%$ is kept within the local economy, and only $20-40 \%$ is kept within the national economy. The remainder stays with the industrialized countries in the form of booking fees, aeroplane flights, hotels and backflows for imported goods and services (Gossling, 1999). These are important issues that must be addressed if any significant biodiversity conservation gains are to be made in this century.

\section{Uncertainty and adaptive management}

Ecological systems are dynamic, and sustainability is not a fixed or determinate end-point (Robinson, 1993, 1998). While a resource may be used sustainably today, no one knows for certain what will happen tomorrow. In reality the best approach to assessing the probability that a use will be sustainable is through a retrospective evaluation of factors that conspired to create overexploitation or that colluded to result in sustainable use. This knowledge is then deployed in management processes to increase the likelihood that use will be sustainable in the future. The IUCN's multidisciplinary approach has concluded that a relatively small range of factors have a disproportionate impact on the likelihood that a species or ecosystem will be used sustainably. These vary from the strictly biological, such as the intrinsic rate of population growth, to the socio-economic and political, such as land tenure, access regimes and enforcement. Therefore, conservation biologists need to appreciate that the management of wild living resources depends as much, if not more, on the human institutions that shape the relations between the resource and its users as it does on the biological productivity of the species concerned (Berkes \& Folke, 1998; Hutton \& Dickson, 2001; O’Riordan \& Stoll-Kleeman, 2002).

Conservation scientists should also recognize that there are distinct limits to the role that science can play in the management of wild living resources. In North America, Australasia and much of Europe, science may be recognized as a cognitive authority that forms the centre ground in the policies and practices of conservation. As a result, conservation scientists from these regions expect decision-makers to codify their advice in sciencebased policy, and resource managers to work to this conceptual blueprint. This is an expensive approach, the export of which to the developing world meets greater challenges: science plays a relatively modest part in the use of living natural resources, conservation biologists are scarce and core funding for research is even scarcer. Therefore, the scientist's voice is usually heard at an inappropriate level, far from the local empiricists directly involved with resource use. Furthermore, economic and social factors conspire to create a high discount rate for natural resources, so the scientist's voice is also muffled in the political process that shapes the institutions which determine the relationships between a resource and its users. As a result, even well understood principles are ignored in decision-making (Ludwig, 2001).

Under these conditions effective management must move beyond physical and biotic data to embrace the structures and dynamics of human activity (Murphree, 2003) including policy, regulation and, inevitably, politics. This creates a complicated management matrix involving great uncertainty, not only with respect to the environment and the abundance of the resource itself, but regarding future socio-economic conditions such as the relationships among users, regulators and consumers (Johnson, 1999). Increasingly, these complex management situations are being approached flexibly, through processes of adaptive management (Holling, 1978) in which management actions are designed as experiments to produce information about the resource being managed. The information and experience gained in this way contribute to management in the face of continued uncertainty and ever-changing conditions. In many cases the experience is more important than the information, 
so that management of sustainable use has the components of both art and science. Adaptive management has its critics, both in terms of its basic premises and its implementation. For example, adaptive management may have struggled to find expression in practical terms, but the type of social learning it proposes may be critical for future management (Lee, 1999). If this is the case, it will be particularly important as the focus of management shifts from the specific resource, often a species, to the level of the ecosystem, where sustainability becomes a much more complex issue.

A final, but important observation with respect to uncertainty concerns the role of the precautionary principle. This is often invoked by those who either oppose the extractive use of certain species or who are concerned that strict biological principles must underpin offtake and harvest. A well-rehearsed argument at CITES meetings, for example, runs along the lines that, lacking detailed and close-to-perfect knowledge of the harvested system, species or population, it is more precautionary to prevent use (Hutton \& Dickson, 2000). If the precautionary principle continues to be used in this way, proponents of use will have to seek and document examples of two kinds. Firstly, examples where precaution has not maintained the target species and populations. Secondly, and conversely, examples of systems where use has continued while management has brought it back into the realm of sustainability. Such examples appear to exist from several fisheries (e.g. Pinkerton, 1989), from meat harvesting in the Peruvian Amazon (e.g. Bodmer \& Puertas, 2000), and from the collection of swiftlet nests in South East Asia (Lim \& Cranbrook, 2002).

\section{Species and ecosystem-specific goals}

Although conservationists may assume that society is interested in sustaining the species or collection of species that are subject to exploitation, the emphasis in many cases is really on sustaining the use itself for human benefit (Robinson, 2001). Therefore, in any situation the goal of management could be the conservation of the exploited species, the ecosystem that contains the exploited species, or the human livelihoods that depend on the exploitation.

Commonly the interests of both conservationists and the consumer are best satisfied by conservation measures that directly target the species. Species conservation is easily understood and often measurable in objective ways (Leader-Williams, 2002a). The biological limits to the sustainable harvesting of species have been well studied, and have allowed approaches to be developed that determine whether offtakes are detrimental to the survival of species, qualitatively (Rosser \& Haywood, 2002) and quantitatively, incorporating principles of uncertainty (Milner-Gulland \& Akcakaya, 2001). However, there is an increasing trend for sustainability to be viewed through the lens of the ecosystem, where the principal goal is to maintain key ecosystem structures and processes while balancing conservation and use and accepting that the human exploitation of natural resources may result in some species being diminished or lost (Callicott \& Mumford, 1997; CBD, 1998).

This new approach has largely been developed within the framework of the CBD and appears to have arisen, at least in part, from the difficulties associated with the management of single species within forest and marine environments. Given the difficulty even of defining an ecosystem, never mind measuring any of its parameters, the real value of this approach is open to question. Twenty-five years after it came into force, the Parties to CITES are still struggling to give practical expression to that part of Article IV of the Convention that requires a species in Appendix II to be maintained "at a level consistent with its role in the ecosystems in which it occurs" (Robinson, 2001; Leader-Williams, 2002b). In addition, the potential for future conflict around sustainable use is alarming when, within an ecosystem approach, it is quite possible to use a species sustainably within its biological limits, but for this to be deemed unsustainable in terms of ecosystem structure or function (e.g. Redford \& Feinsinger, 2001). The complications that arise from the introduction of the ecosystem concept highlight the critical importance of including unambiguous and transparent management goals in adaptive management processes.

An equally daunting challenge is that direct-use values of wild living resources may not serve as sufficient incentive to ensure the continued flow of ecosystem services upon which all of humanity depends. Calculations of the full value of wild living resources, including the indirect value of ecosystem services, remain in their infancy (Costanza et al., 1997), and are as yet rarely incorporated into political decision-making (Daily, 1997). Thus, the indirect use of ecosystem services appears free at the point of entry, when in fact some estimates suggest their total economic value may be even greater than the global GNP that is captured in traditional markets (Costanza et al., 1997). Furthermore, developed countries invest heavily in perverse subsidies that support activities that damage the environment and support habitat conversion (Myers \& Kent, 2001). If our use of ecosystem services was actually paid for, in terms of their contribution to the global economy, and perverse subsidies were phased out, the global pricing system would be very different from its current state, and would allow policies to better define incentives that promote 
sustainable use. In other words, the conservation of wild living resources needs to compete on a level playing field with our other economic activities. Bringing this agenda into the arena of political decision making will perhaps prove the greatest, and the most important institutional challenge of all (Balmford et al., 2002; Myers, 2002), given the dependency by all of humanity on a functioning planet and the sustainable use of its resources.

\section{Conclusions}

Sustainable use has become, and still remains, a polarized issue within the conservation community. Much polemic arises from the route maps that conservationists of different persuasions wish to follow to achieve their objectives, and also from our failure to distinguish between, and label, the different ideas that have nestled under the umbrella term of 'sustainable use'. The direct use of resources subject to exploitation will remain an imperative for many, and therefore inevitable. However, much of that use is currently not sustainable biologically. The twin challenges remain, firstly, to ensure that use increasingly becomes biologically sustainable and, secondly, that wherever possible it serves as a conservation strategy to conserve specific resources and prevent the conversion of land to uses that are incompatible with biodiversity conservation. The first is not controversial, but for some the second is. A more harmonious understanding of the different concepts that are currently encompassed within the term sustainable use may result through the adoption of the term 'incentive-driven conservation'.

At the same time, irrespective of semantics, we recognize that people will continue to use wild living resources and, furthermore, that in a more populated world this use could increasingly result in overexploitation and resource depletion. In response the conservation community can follow one of two paths. It can either try to stop use or it can work to introduce the means to deliver sustainable use and, if possible, incentive-driven conservation. Because much of humanity would find it impossible to stop their use of wild living resources, even if it was ethically acceptable to attempt to halt such use, an essential challenge for conservation in this century is to reposition sustainable use and incentive-driven conservation at the centre of conservation activity in human-dominated landscapes.

\section{Acknowledgements}

We thank Rick Bodmer, Roy Ellen, Raj Puri, Alison Rosser, John Robinson and Jeff McNeely for their advice and comments. Our perspectives on sustainable use have evolved over many years and many colleagues and authors have been important in this process. We are grateful that they shared their wisdom and apologize if they consider we have not made good use of it.

\section{References}

Adams, J.S. \& McShane, T.O. (1992) The Myth of Wild Africa: Conservation Without Illusion. Norton, New York, USA.

Balmford, A., Moore, J.L., Brooks, T., Burgess, N., Hansen, L.A., Williams, P. \& Rahbek, C. (2001) Conservation conflicts across Africa. Science, 291, 2616-2619.

Balmford, A., Bruner, A., Cooper, P., Costanza, R., Farber, S., Green, R.E., Jenkins, M., Jefferiss, P., Jessamy, V., Madden, J., Munro, K., Myers, N., Naeem, S., Paavola, J., Rayment, M., Rosendo, S., Roughgarden, J., Trumper, K. \& Turner, R.K. (2002) Economic reasons for conserving wild nature. Science, 397, 950-953.

Barrett, C. \& Arcese, P. (1995) Are Integrated Conservation and Development Projects (ICDPs) sustainable? On the conservation of large mammals in sub-Saharan Africa. World Development, 23, 1073-1084.

Berkes, F. \& Folke, C. (eds) (1998) Linking Social and Ecological Systems: Management Practices and Social Mechanisms for Building Resilience. Cambridge University Press, Cambridge, UK.

Bodmer, R. \& Puertas, P.E. (2000) Community-based co-management of wildlife in the Peruvian Amazon. In Hunting for Sustainability in Tropical Forests (eds J.R. Robinson \& E. Bennett), pp. 395-409. Columbia University Press, Columbia, USA.

Bond, I. (1994) Importance of elephant hunting to CAMPFIRE revenue in Zimbabwe. Traffic Bulletin, 14, 117-119.

Bowen-Jones, E. (2003) Bushmeat: traditional regulation or adaptation to market forces. In The Trade in Wildlife: Regulation for Conservation (ed S. Oldfield), pp. 132-145. Earthscan, London, UK.

Bruner, A.G., Gullison, R.E., Rice, R.E. \& Fonseca, G.A.B. (2001) Effectiveness of parks in protecting tropical biodiversity. Science, 291, 125-128.

Callicott, J.B. \& Mumford, K. (1997) Ecological sustainability as a conservation concept. Conservation Biology, 11, 32-40.

Caughley, G. (1977) Analysis of Vertebrate Populations. John Wiley, New York, USA.

Caughley, G. \& Gunn, A. (1996) Conservation Biology in Theory and Practice. Blackwell, Oxford, UK.

Convention on Biological Diversity (CBD) (1998) Report of the workshop on the ecosystem approach. Lilongwe, Malawi. UNEP CBD CoP4/Inf.9 (20 March 1998).

Child, G. (1995) Wildlife and People: the Zimbabwean Success. Wisdom Foundation, Harare, Zimbabwe.

Clark, C.W. (1973) The economics of overexploitation. Science, 181, 630-634.

Clark, C.W. (1990) Mathematical Bioeconomics. Wiley, New York, USA. 
Colding, J. \& Folke, C. (1997) The relations among threatened species, their protection and taboos. Conservation Ecology [online], 1(1), 6. http:/ / www.consecol.org/vol1/iss1/art6 [accessed 4 April 2003].

Costanza, R., d'Arge, R., de Groot, R., Farber, S., Grasso, M., Hannon, B., Limburg, K., Naeem, S., O'Neill, R.V., Paruelo, J., Raskin, R.G., Sutton, P. \& van den Belt, M. (1997) The value of the world's ecosystem services and natural capital. Nature, 387, 253-260.

Cunningham, A.B. (2001) Applied Ethnobotany: People, Wild Plant Use and Conservation. Earthscan, London, UK.

Daily, G.C. (1997) Nature's Services: Societal Dependence on Natural Ecosystems. Island Press, Washington, DC, USA.

Diamond, J.M. (1989) Overview of recent extinctions. In Conservation for the Twenty-first Century (ed. D. Western \& M. Pearl), pp. 37-75. Oxford University Press, New York, USA.

Eltringham, S.K. (1984) Wildlife Resources and Economic Development. Wiley, Chichester, UK.

Freese, C.H. (1997) The 'use it or lose it' debate. In Harvesting Wild Species: Implications for Biodiversity Conservation (ed. C.H. Freese), pp. 1-48. John Hopkins University Press, Baltimore, USA.

Gadgil, M. \& Vartak, V.D. (1974) The sacred groves of Westren Ghats in India. Economic Botany, 30, 152-160.

Getz, W.M., Fortmann, L., Cumming, D.H.M., du Toit, J., Hilty, J., Martin, R.B., Murphree, M., Owen-Smith, N., Starfield, A.M. \& Westphal, M.I. (1999) Sustaining natural and human capital: villagers and scientists. Science, 283, 1855-1856.

Ghimire, K.B. \& Pimbert, M.P. (eds) (1997) Social Change and Conservation: Environmental Politics and Impacts of National Parks and Protected Areas. Earthscan, London, UK.

Goodwin, H.J. \& Leader-Williams, N. (2000) Tourism and protected areas: distorting conservation priorities towards charismatic megafauna? In Priorities for the Conservation of Mammalian Diversity: Has the Panda had its Day? (ed.

A. Entwistle \& N. Dunstone), pp. 257-275. Cambridge University Press, Cambridge, UK.

Gossling, S. (1999) Ecotourism: a means to safeguard biodiversity and ecosystem functions? Ecological Economics, 29, 303-320.

Hilton-Taylor, C. (compiler) (2000) 2000 IUCN Red List of Threatened Species. IUCN, Gland, Switzerland and Cambridge, UK.

Holling, C.S. (ed.) (1978) Adaptive environmental assessment and management. John Wiley, New York, USA.

Hoyt, J. (1994) Animals in Peril: How Sustainable Use is Wiping Out the World's Wildife. Avery, New York, USA.

Honey, M. (1999) Ecotourism and Sustainable Development: Who Owns Paradise? Island Press, Washington, DC, USA.

Hulme, D. \& Murphree, M. (1999) Communities, wildlife and the 'new conservation' in Africa. Journal of International Development, 11, 277-285.

Hutton, J.M. \& Dickson, B. (2000) Endangered Species, Threatened Convention: the Past, Present and Future of CITES. Earthscan, London, UK.
Hutton, J.M. \& Dickson, B. (2001) Conservation out of exploitation: a silk purse from a sow's ear. In Conservation of Exploited Species (eds J.D. Reynolds, G.M. Mace, K.H. Redford \& J.G. Robinson), pp. 440-461. Cambridge University Press, Cambridge, UK.

Hutton, J.M. \& Games, I. (1992) The CITES Nile Crocodile Project. CITES Secretariat, Lausanne, Switzerland.

Inamdar, A., de Jode, H., Lindsay, K. \& Cobb, S. (1999) Capitalising on nature: protected area management. Science, 283, 1856-1857.

Ingold, T., Riches, D. \& Woodburn, J. (1988) Hunters and Gatherers: History, Evolution and Social Change. BERG, Oxford, UK.

IUCN (1998) 1997 United Nations List of Protected Areas. IUCN, Gland, Switzerland and Cambridge, UK.

IUCN (2000) The IUCN Policy Statement on Sustainable Use of Wild Living Resources. http:/ /www.iucn.org/themes/ sustainableuse/policy/polstateng.html [accessed 7 April 2003].

Janzen, D.H. (1994) Wildland biodiversity management in the tropics: where are we now and where are we going? Vida Silvestre Neotropical, 3, 3-15.

Johnson, B.L. (1999) Introduction to the special feature: adaptive management - scientifically sound, socially challenged? Conservation Ecology [online], 3(1), 10. http://www.consecol.org/vol3/iss1/art10 [accessed 4 April 2003].

Knight, J. (2000) Introduction. In Natural Enemies: People Wildlife Conflicts in Anthropolgical Perspective (ed. J. Knight), pp. 1-35. Routledge, London, UK.

Lavigne, D.M., Callaghan, C.J., \& Smith, R.J. (1996) Sustainable utilization: the lessons of history. In The Exploitation of Mammal Populations (eds V.J. Taylor \& N. Dunstone), pp. 250-264. Chapman \& Hall, London, UK.

Leader-Williams, N. (2000) The effects of a century of policy and legal change upon wildlife conservation and utilisation in Tanzania. In Conservation of Wildlife by Sustainable Use (eds H.H.T. Prins, J.G. Grootenhuis \& T.T. Dolan), pp 219-245. Kluwer Academic Publishers, Boston, USA.

Leader-Williams, N. (2002a) Animal conservation, carbon and sustainability. Philosophical Transactions of the Royal Society, A, 360, 1787-1806.

Leader-Williams, N. (2002b) When is international trade in wild animal detrimental to survival? Principles, avoidance and monitoring. In Guidance for CITES Scientific Authorities: Checklist to Assist in Making Non-detriment Findings for Appendix II Exports (ed. A.M. Rosser \& M. Haywood), pp. 7-16. IUCN, Gland, Switzerland and Cambridge, UK.

Leader-Williams, N., Harrison, J. \& Green, M.J.B. (1990) Designing protected areas to conserve natural resources. Science Progress, 74, 189-204.

Leakey, R.E. (1981) The Making of Mankind. Abacus, London, UK.

Lee, K.N. (1999) Appraising adaptive management. Conservation Ecology [online], 3(2), 2. http://www.consecol.org/vol3/ iss2/art2 [accessed 4 April 2003].

Lim, C.K. \& Cranbrook, Earl of (2002) Swiftlets of Borneo: Builders of Edible Nests. Natural History Publications (Borneo), Sabah, Malaysia. 
Ludwig, D. (2001) Can we exploit sustainably? In Conservation of Exploited Species (eds J.D. Reynolds, G.M. Mace, K.H. Redford \& J.G. Robinson), pp. 16-38. Cambridge University Press, Cambridge, UK.

Lundberg, D.E., Stavenga, M.H. \& Krishnamoorthy, M. (1995) Tourism Economics. John Wiley, New York, USA.

McNeely, J. (1988) Economics and Biological Diversity: Developing and Using Economic Incentives to Conserve Biological Resources. IUCN, Gland, Switzerland and Cambridge, UK.

McNeely, J. (1995) Expanding Partnerships in Conservation. Island Press, Washington, DC, USA.

Milner-Gulland, E.J. \& Akcakaya, H.R. (2001) Sustainability indices for exploited populations. Trends in Ecology and Evolution, 16, 586-692.

Milner-Gulland, E.J., Beddington, J.R. \& Leader-Williams, N. (1992) Dehorning African rhinos: a model of optimal frequency and profitability. Proceedings of the Royal Society, B, 249, 83-87.

Milner-Gulland, E.J. \& Mace, R. (1998) Conservation of Biological Resources. Blackwell, Oxford, UK.

Misra, M. (2003) Evolution, impact and effectiveness of domestic wildlife bans in India. In The Trade in Wildlife: Regulation for Conservation (ed. S. Oldfield), pp. 78-85. Earthscan, London, UK.

Monela, G.C., Kajembe, G.C., Kaoneka, A.R.S. \& Kowero, G. (1999) Household Livelihood Strategies in the Miombo Woodlands: Emerging Trends. Sokoine University of Agriculture, Morogoro, Tanzania.

Moyle, B. (2003) Regulation, conservation and incentives. In The Trade in Wildlife: Regulation for Conservation (ed. S. Oldfield), pp. 41-51. Earthscan, London, UK.

Murphree, M. (2003) Control and the Holy Grail. In The Trade in Wildlife: Regulation for Conservation (ed. S. Oldfield), pp. 52-60. Earthscan, London, UK.

Myers, N. (2002) Biodiversity and biodepletion: the need for a paradigm shift. In Biodiversity, Sustainability and Human Communities: Protecting Beyond the Protected (eds T. O'Riordan \& S. Stoll-Kleeman), pp. 46-60. Cambridge University Press, Cambridge, UK.

Myers, N. \& Kent, J. (2001) Perverse Subsidies: How Tax Dollars can undercut the Environment and the Economy. Earthscan, London, UK.

Noss, R.F. (1991) Sustainability and wilderness. Conservation Biology, 5, 120-122.

Oates, J.F. (1995) The dangers of conservation by rural development: a case study from Nigeria. Oryx, 29, 115-122.

Oldfield, S. (ed.) (2003) The Trade in Wildlife: Regulation for Conservation. Earthscan, London, UK.

O'Riordan, T. \& Stoll-Kleeman, S. (eds) (2002) Biodiversity, Sustainability and Human Communities: Protecting Beyond the Protected. Cambridge University Press, Cambridge, UK.

Orlove, B.S. \& Brush, S.B. (1996) Anthropology and the conservation of biodiversity. Annual Review of Anthropology, $25,329-352$.

Ostrom, E., Burger, J., Field, C.B., Norgaard, R.B., \& Policansky, D. (1999) Revisiting the commons: local lessons, global challenges. Science, 284, 278-282.

Pinkerton, E. (1989) Attaining better fisheries management through co-management: prospects, problems and propositions. In Co-operative Management of Local Fisheries: New Directions for Improved Management and Community Development (ed. E. Pinkerton), pp. 3-33. University of British Columbia Press, Vancouver, Canada.

Prescott-Allen, R. \& Prescott-Allen, C. (1982) What's Wildlife Worth? Economic Contributions of Wild Plants and Animals to Developing Countries. International Institute for Environment and Development \& Earthsan, London, UK.

Pretty, J.N. (2002) People, livelihoods and collective action in biodiverity management. In Biodiversity, Sustainability and Human Communities: Protecting Beyond the Protected (eds T. O'Riordan \& S. Stoll-Kleeman), pp. 61-86. Cambridge University Press, Cambridge, UK.

Rasker, R. \& Freese, C.H. (1995) Wildlife in the marketplace: opportunities and problems. In On Fundamental Policies in Wildlife Conservation. (eds V.Geist \& I. McTaggart-Cowan), pp. 177-204. Detselig Publishers, Calgary, Canada.

Redford, K.H. \& Feinsinger, P. (2001) The half empty forest: sustainable use and the ecology of interactions. In Conservation of Exploited Species (eds J.D. Reynolds, G.M. Mace, K.H. Redford \& J.G. Robinson), pp. 370-399. Cambridge University Press, Cambridge, UK.

Redford, K.H. \& Robinson, J.G. (1991) Subsistence and commercial uses of wildlife in Latin America. In Neotropical Wildlife Use and Conservation (eds J.G. Robinson \& K.H. Redford), pp. 6-23. University of Chicago Press, Chicago, USA.

Reynolds, J.D., Mace, G.M., Redford, K.H. \& Robinson, J.G. (eds) (2001) Conservation of Exploited Species. Cambridge University Press, Cambridge, UK.

Roberts, C.M., Bohnsack, J.A., Gell, F., Hawkins, J.P. \& Goodridge, R. (2002) Marine reserves and fisheries management. Science, 295, 1234-1235.

Robinson, J.G. (1993) The limits to caring: sustainable living and the loss of biodiversity. Conservation Biology, 7, 20-28.

Robinson, J.G. (1998) Evolving understanding of sustainable use. In Enhancing Sustainability: Resources for our Future (eds H.A. van der Linde \& H.M. Danskin), pp. 3-6. IUCN, Gland, Switzerland and Cambridge, UK.

Robinson, J.G. (2001) Using 'sustainable use' approaches to conserve exploited populations. In Conservation of Exploited Species (eds J.D. Reynolds, G.M. Mace, K.H. Redford \& J.G. Robinson), pp. 485-498. Cambridge University Press, Cambridge, UK.

Robinson, J.R. \& Bennett, E. (eds) (2000) Hunting for Sustainability in Tropical Forests. Columbia University Press, Columbia, USA.

Robinson, J.G. \& Redford, K.H. (1991) Sustainable harvest of neotropical forest mammals. In Neotropical Wildlife Use and Conservation (eds J.G. Robinson \& K.H. Redford), pp. 415-429. University of Chicago Press, Chicago, USA.

Roe, D., Leader-Williams, N. \& Dalal-Clayton, D. B. (1997). Take only Photographs, Leave only Footprints: the Environmental Impacts of Wildlife Tourism. International Institute for Environment and Development, London, UK.

Roe, D., Mulliken, T., Milledge, S., Mremi, J., Mosha, A. \& Grieg-Gran, M. (2002) Making a Killing or Making a Living? Wildlife Trade, Trade Controls and Rural Livelihoods. International Institute for Environment and Development, London, UK. 
Rosser, A.M. \& Haywood, M. (eds) (2002) Guidance for CITES Scientific Authorities: Checklist to Assist in Making Nondetriment Findings for Appendix II Exports. IUCN, Gland, Switzerland and Cambridge, UK.

Sanderson, H. \& Prendergast, H.D.V. (2002) Commercial Uses of Wild and Traditionally Managed Plants in England and Scotland. Royal Botanic Gardens Kew, London, UK. http://www.rbgkew.org.uk/scihort/commusesreport.pdf [accessed 4 April 2003].

Scoones, I., Melnyk, M. \& Pretty, J.N. (1992) The Hidden Harvest: Wild Foods and Agricultural Ecosystems. International Institute for Environment and Development, London, UK.

Soulé, M.E. \& Sanjayan, M.A. (1998) Conservation targets: do they help? Science, 279, 2060-2061.

Terborgh, J. (1999) Requiem for Nature. Island Press, Washington, DC, USA.

TRAFFIC. (2003) East Asia: a quarter of the world. TRAFFIC Dispatches, 20, [also at http:/ /www.traffic.org, accessed 4 April 2003].

Vitousek, P.M., Ehrlich, P.R., Ehrlich, A.M. \& Matson, P.R. (1986) Human appropriation of the products of photosynthesis. Bioscience, 36, 368-373.

Western, D. \& Wright, R.M. (eds) (1994) Natural Connections: Perspectives in Community-based Conservation. Island Press, Washington, DC, USA.

\section{Biographical sketches}

Jon Hutton worked as an ecologist in southern Africa for more than 20 years. He is interested in a wide range of conservation issues, particularly the sustainable use of biodiversity and the way rural communities craft their livelihood strategies from the use of living natural resources. He is currently Regional Director for Africa at Fauna \& Flora International as well as Director of Resource Africa in the European Union, and is Chairman of the IUCN/SSC Sustainable Use Specialist Group.

Nigel Leader-Williams is also interested in a wide range of conservation issues, including sustainable use of natural resources, law enforcement and illegal use in protected areas, conservation on private and communal land, and human-animal conflict. He has studied the ecology of introduced reindeer on South Georgia and the ecology and conservation of black rhinos in Zambia, and was an adviser to the government of Tanzania on wildlife policy. He is currently Professor of Biodiversity Management and Director of the Durrell Institute of Conservation and Ecology at the University of Kent, UK. 